\title{
Is love a flimsy foundation? Soulmate versus institutional models of marriage
}

\author{
W. Bradford Wilcox \\ University of Virginia \\ Jeffrey P. Dew \\ Brigham Young University - Provo, jeff_dew@byu.edu
}

Follow this and additional works at: https://scholarsarchive.byu.edu/facpub

Part of the Other Social and Behavioral Sciences Commons

\section{Original Publication Citation}

Wilcox, W. B., \& Dew, J. P. (2010). Is love a flimsy foundation?: Soulmate versus institutional models of marriage. Social Science Research, 39, 687-699.

\section{BYU ScholarsArchive Citation}

Wilcox, W. Bradford and Dew, Jeffrey P., "Is love a flimsy foundation? Soulmate versus institutional models of marriage" (2010). Faculty Publications. 4517.

https://scholarsarchive.byu.edu/facpub/4517 


\title{
Is love a flimsy foundation? Soulmate versus institutional models of marriage is
}

\author{
W. Bradford Wilcox ${ }^{\mathrm{a}, *}$, Jeffrey Dew ${ }^{\mathrm{b}, 1}$ \\ ${ }^{a}$ National Marriage Project, University of Virginia, P.O. Box 400766, Charlottesville, VA 22904-4766, USA

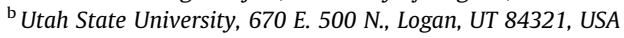

\section{A R T I C L E I N F O}

\section{Article history:}

Available online 1 June 2010

\section{Keywords:}

Marital conflict

Divorce

Marital satisfaction

Soulmate

Gender

Religion

Social integration

\begin{abstract}
A B S T R A C T
Steven Nock argued that love-understood narrowly in terms of emotional and sexual intimacy-was a flimsy foundation for relationships and that the institution of marriage provided a firmer footing for stable, high-quality relationships than love alone. Relying on data from the Marriage Matters Survey of 1414 married men and women in Louisiana (1998-2004), we extended Nock's insights to consider whether contemporary marriages organized along institutional lines enjoyed more stability, satisfaction, and less conflict than marriages organized around a soulmate model. Largely consistent with Nock's perspective, we found that individuals who embraced norms of marital permanency and gender specialization and were embedded in social networks and religious institutions enjoyed high-quality stable marriages, so long as they also focused on the expressive dimension of married life. By contrast, spouses who embraced a soulmate model of marriage experienced high levels of satisfaction but also experienced high levels of conflict and divorce. Finally, spouses who embraced traditional norms about marriage without the benefit of social support for those norms reported low levels of marital quality.
\end{abstract}

(c) 2010 Elsevier Inc. All rights reserved.

"Though we both know how impossible our distances are, how different our lives are, all those different things we know in my professional work, my family, all those different things. I will be able to die knowing [sobs] that I had met my soul mate".-South Carolina Gov. Mark Sanford. ${ }^{2}$

\section{Introduction}

Governor Mark Sanford's description of his recent relationship with Argentinian journalist Maria Belen Chapur captures, in an ideal-typical manner, the contemporary soulmate model of relationships. Romantic relationships can be established and pursued between two persons who do not share a native tongue, a country of residence, a common way of life, a religious faith, or the support of their friends and families. Moreover, as this case illustrates, the soulmate model of relationships is not particularly concerned with norms of marital fidelity or permanency. Instead, the soulmate model of relationships places a premium on each partner's innermost needs or desires, that is, on their sense that a relationship is delivering the emotional and sexual intimacy that affords them a sense of personal fulfillment (Amato, 2009; Whitehead and Popenoe, 2001).

\footnotetext{
This study was supported in part by a grant from the Social Trends Institute.

* Corresponding author. Fax: +1 4349247028.

E-mail addresses: wbwilcox@virginia.edu (W.B. Wilcox), jeff.dew@usu.edu (J. Dew).

1 Fax: +1 4357977220 .

2 http://www.nydailynews.com/news/politics/2009/07/02/2009-07-02_sanford_tears_up_again_over_soul_mate.html.
} 
But, as Steven Nock observed, this type of love is a flimsy foundation for marriage (Nock, 1995). If love is understood in the narrow expressive, sexual, and especially individualistic terms advanced by the soulmate model of relationships, it is not likely to foster marital stability. After all, for both sociological and biological reasons, emotional intimacy and sexual attraction are likely to ebb and flow in most marriages (Fisher, 2005; Nock, 1995). Moreover, couples who organize their lives together around a soulmate "marriage schemata" are probably less likely to identify with and be nested within the social and normative bonds traditionally associated with a more institutional model of marriage (Amato, 2009; Wilcox and Nock, 2006). Accordingly, if one or both of the spouses in a soulmate marriage comes to the conclusion that a marriage is not meeting their needs, then "divorce is viewed as inevitable and necessary" (Amato, 2009, p. 79).

By contrast, spouses who take an institutional approach to marriage that links their marriage to norms related to marital permanency, mutual aid, and childbearing and childrearing, to social networks of friends and family who take their marriage seriously, and to religious institutions that lend ritual power to their relationship are likely to enjoy markedly more stable marriages than their peers who take a soulmate approach to their relationship (Nock, 1998, 2006; Wilcox and Nock, 2006). The marriage-friendly culture and social structure associated with an institutional model of marriage mean that couples do not have to rely upon the fragile foundations of feelings and sexual attraction to sustain their marriage. Instead, they can rely on the cultural and social structural supports and constraints associated with the institutional model of marriage to supplement the expressive dimension of their relationship and sustain their marriages over the long term.

Most scholars would not dispute the notion that the institutional model of marriage is more likely to deliver marital stability than is the soulmate model of marriage. Scholars do not know, however, whether the soulmate or the institutional model of marriage is more likely to deliver high marital quality to contemporary U.S. spouses. On the one hand, couples who focus on an expressive relationship may be more likely to demand and achieve marital happiness (Coontz, 2005). On the other hand, couples who take a broader view of the purposes of marriage, put a premium on marital permanency, enjoy the support of friends and family, and are religious may invest more in their marriages and take a more realistic view of their relationships-both of which may foster higher levels of marital quality (Wilcox and Nock, 2006).

Accordingly, using data from three waves of the Marriage Matters Survey (MMS) of 1414 married men and women in Louisiana (1998-2004), we use latent class analysis to explore three different research questions. First, we use latent class analysis to determine if couples in this sample cluster into groups than can be classified as conforming to the soulmate and institutional models of marriage described below, or some companionate hybrid of the two models. Second, we examine the association between adhering to an institutional, soulmate, or hybrid model of marriage at Wave 1 and reports of marital satisfaction and marital conflict at Wave 2. Third, we explore how adhering to the institutional, soulmate, or hybrid model of marriage at Wave 1 is linked to reports of divorce by Wave 3. By analyzing the associations between the norms, networks, and religiosity of newly-married couples in Louisiana and their marital happiness and stability, this study sheds some light on whether a soulmate, an institutional, or a hybrid approach to marriage is more likely to deliver high levels of marital stability and quality to contemporary couples.

\section{Literature review}

Over the course of the last half-century, three social revolutions-the psychological revolution, the gender revolution, and the secular revolution-have profoundly reshaped the character, quality, and stability of marriage in the West (Popenoe, 2009; Wilcox, 2004). The psychological revolution-marked by the rise of expressive individualism and a concomitant decline in the scope and normative power of social institutions-has resulted in marriages that, on the one hand, focus more on the emotional dimensions and the individual satisfactions of married life and, on the other hand, do not enjoy the normative commitment to lifelong marriage or connect marriage to childbearing and childrearing in ways that earlier marriages did (Cherlin, 2009; Wilcox and Nock, 2006; Whitehead, 1998). The gender revolution-marked by dramatic increases in women's labor force participation and popular support for gender egalitarianism-has resulted in marriages where both spouses typically work, husbands do markedly more housework and childcare than they did fifty years ago, and most spouses expect that they will share, at least to some degree, the domestic, emotional, and market work associated with maintaining a family (Bianchi et al., 2006; Casper and Bianchi, 2002). The secular revolution-marked by declines in religious practice and belief, as well as religious moral authority-has resulted in marriages that, on the one hand, are less committed and more contingent and, paradoxically, on the other hand, have to carry a greater emotional load, insofar as people seem to endow their marriages with greater ultimate significance now that they accord less significance to religion (Bellah et al., 1985; Fowers, 2000; Thornton, 1985).

The influence of these revolutions on marriage has been complex; many changes have been positive-one thinks, for instance, of how the gender revolution has encouraged husbands to invest more in the emotional lives of their wives and children. Nevertheless, these three revolutions have posed, both individually and in concert, serious challenges to the institution of marriage over the last five decades. More specifically, many scholars argue that these revolutions have helped to deinstitutionalize marriage-that is, weaken its normative and practical connection to sex, childbearing, childrearing, and the adult life course, and its social structural links to other institutions, such as religion-and to push marriage in a more expressive direction, where its primary purpose is to supply individual spouses with emotional fulfillment (Amato et al., 2007; Cherlin, 2004; Nock, 2005). Indeed, recent research suggests that many adults have come to see marriage as an expressive "superrelationship" for soulmates, rather than as an institution governed by a host of norms that are intended to unite spouses in a 
lifelong relationship, encourage the bearing and rearing of children, cultivate mutual dependency, gender specialization, and foster a shared religious faith (Whitehead and Popenoe, 2001).

These developments are important because marriage plays an important role in fostering the social, psychological, and economic welfare of children, adults, and communities; in particular, children are more likely to thrive when they are reared in a household headed by their own married parents (Amato, 2005; McLanahan and Sandefur, 1994). They are also important because we do not know if marriages organized around a soulmate or expressive model are better able to secure marital happiness and stability (Coontz, 2005; Giddens, 1991) than marriages organized around an institutional model (Amato, 2009; Wilcox and Nock, 2006). Given recent shifts in marriage in American life, this study seeks to determine whether the institutional or soulmate models are now better able to supply marital happiness and marital stability to newly-married couples in the United States.

The soulmate model of marriage focuses on the emotional and individual possibilities of married life. Adults in America who subscribe to the soulmate schemata of marriage largely see marriage as an expressive "super-relationship" designed to secure them personal growth, emotional intimacy, and individual fulfillment (Whitehead and Popenoe, 2001). They do not link marriage to the other classic functions it served besides intimacy-children, mutual aid, economic cooperation, gender specialization, and, for many, a shared religious faith (Amato, 2009). Instead, adherents of the soulmate model of marriage aim to find happiness in marriage by focusing on it directly.

When it comes to divorce, most family scholars would predict that adherents of the soulmate model are more likely to divorce, given the relatively fluid character of sexual attraction and the emotional ties between two adults. In the words of Stephanie Coontz (2005, p. 306): "Marriage has become more joyful, more loving, and more satisfying for many couples than ever before in history. At the same time it has become optional and more brittle. These two strands of change cannot be disentangled". Moreover, adherents to the soulmate model would have fewer of the normative commitments to marital permanency, children, and mutual aid that might serve as barriers to divorce (Nock, 2006; Wilcox and Nock, 2006). Finally, adherents to the soulmate model are less likely to be integrated into the social institutions-such as churches-that provide social support for marital permanency, as well as rituals and beliefs that invest marriage with transcendent power (Amato, 2009; Giddens, 1991; Wilcox, 2004). For these reasons, most scholars would expect that married couples who take a soulmate approach to marriage are more likely to end up divorced.

But what about their marital happiness? Many proponents of the soulmate model would argue that its focus on the emotional life of the couple, its egalitarian ethos, its flexibility, and its attentiveness to the needs of individuals within marriage is likely to foster higher levels of happiness within marriage (Coontz, 1992, 2005; Giddens, 1991; Scanzoni, 1991). Specifically, adults who embrace the soulmate model of marriage are more likely to see marriage as an opportunity to enjoy companionship, personality development, and emotional security within a relationship than adults who take a more institutional view of marriage (Amato et al., 2007, p. 16). Given the expressive focus of their relationship, they are also more likely to invest themselves in the emotional possibilities of their marital relationship (Giddens, 1991). Moreover, because of the expressive character of contemporary married life, where marital happiness is closely linked to the exchange of emotional intimacy between spouses (Wilcox and Nock, 2006), this expressive focus is likely to foster higher levels of marital quality. Finally, spouses who adopt a soulmate ethic and are not happy with their marriage should be more likely to divorce; accordingly, those who remain married should be happier in their marriages than couples who take a more institutional model approach to marriage and remain in their marriages even when they are unhappy. This, then, is why Coontz (2005, p. 306) believes that the emergence of the soulmate model of marriage on a large scale in contemporary society has made marriages "more joyful, more loving, and more satisfying than ever before in history".

In addition, the soulmate model of marriage may be particularly suited for the contemporary zeitgeist, which both reinforces and legitimates the individualistic and expressive character of the soulmate model of marriage. First, the expressive ethic associated with the soulmate model of marriage is reinforced by a popular culture that celebrates intense emotional relationships in music, movies, television, and literature (Coontz, 2005; Radway, 1991). The soulmate model of marriage is also consistent with the hedonistic ethic of contemporary capitalism, where the market seeks to cultivate and meet a range of individual needs and desires (Bell, 1976). For all these reasons, proponents of the soulmate model of marriage, such as Stephanie Coontz $(1992,2005)$, would argue that, in today's society, spouses are more likely to experience marital happiness in a relationship organized around an expressive ethic that maximizes individuals' personal fulfillment.

Accordingly, we test the following hypothesis:

Hypothesis 1: Marriages organized according to the soulmate model enjoy higher levels of marital quality and lower levels of marital stability.

The institutional model of marriage advanced by Steven Nock and others, however, would predict that couples who adhere to an institutional model of marriage (Nock, 1998, 2006; Wilcox and Nock, 2006) are most likely to enjoy not only stable marriages, but also happy ones. The basic idea is that marriage has traditionally been associated with a series of norms that guide men's and women's conduct in their marital roles as husband and wife, encouraging them to invest in one another, their relationship, as well as a number of other goods, such as children, economic cooperation, and their kin relationships. Moreover, these norms and roles are reinforced by social networks and other institutions-churches, the state, businesses, etc.-that lend social support and social control to marriage. Thus, the culture and social structure 
associated with this institutional model reinforce one another, lending order, meaning, security, and purpose to contemporary marriages. The institutional model of marriage predicts that the more that men and women embrace an institutional model of marriage, and are embedded in social structures that reinforce and reward this model, the more likely they are to experience the benefits of married life, both in terms of quality and stability. Thus, we hypothesize that there is a categorical difference between institutionalized marriages and soulmate marriages in much the same way there is a categorical difference between cohabiting couples who plan to marry and cohabiting couples who do not have plans to marry (Brown and Booth, 1996). In a word, the more spouses embrace the married state, and the institutional norms that go with it, the more they enjoy it.

\subsection{Norms}

Marriage has traditionally been associated with norms about marital permanency, fidelity, mutual aid, parenthood, and gender complementarity (Nock, 1998, 2006). A large body of research on marriage indicates that a normative commitment to lifelong marriage, along with an individual commitment to the welfare of one's spouse, are linked to happier, more stable marriages (Fowers, 2000; Neff and Karney, 2009; Stanley et al., 2004, 2006; Wilcox and Nock, 2006). Although a growing number of married people in the West, influenced by a cultural logic of "expressive individualism" (Bellah et al., 1985), act as self-interested agents who bargain over their marital roles and interests in an effort to maximize their individual fulfillment, others are devoted to the ideal of unconditional marital love; this ideal is given normative expression in a commitment to honoring marital vows that means forswearing divorce, except in cases of abuse, adultery, or abandonment.

Many spouses also have a strong personal devotion to the welfare of their spouses. Spouses who hold a normative commitment to marriage and/or a strong commitment to their spouse are more likely to invest in their marriages, to be generous and sacrificial to their spouses, and to remain faithful. Such behaviors typically promote the marital happiness of their spouses and also tend to redound to their benefit, as their spouses respond to these displays of unconditional love with similar gestures of their own (Stanley et al., 2006; Amato and Rogers, 1999).

Finally, when couples share a high degree of normative or individual commitment, they are more likely to trust one another and to take a long-term view of their marriage, both of which are likely to benefit their marriage (Brines and Joyner, 1999; Wieselquist et al., 1999; Wilcox and Nock, 2006). For all these reasons, spouses who believe and behave in ways consistent with an ethic of unconditional love and marital permanency are more likely to be happy in their marriages and more likely to avoid divorce than spouses who do not embrace this ethic.

The institutional model of marriage would also predict that spouses who connect marriage with its classic functions-parenthood, mutual aid, and gender specialization-are more likely to enjoy high-quality, stable relationships. Spouses who take this more expansive view of the purposes of marriage are likely to benefit from focusing on common projects, from childrearing to economic cooperation, that orient them away from themselves and towards a variety of marital goods besides just emotional and sexual intimacy. This is likely to reduce the importance of the expressive dimensions of married life for these couples, and to allow them to build and maintain other grounds for marital happiness and success (Lambert and Dollahite, 2006; Lambert, 2008; Fowers, 2000). Couples who value gender complementarity may be more likely to embrace a gendered approach to their interactions and their division of family-work roles that fosters a sense of order, dependence, and direction to their relationship as each spouse makes distinctive contributions to the marriage (Hakim, 2001; Wilcox and Nock, 2006). Moreover, couples who embrace gender specialization may be more comfortable with the persistent gender inequalities in the division of household labor and childrearing that confront most couples (Demaris and Longmore, 1996). In sum, spouses who subscribe to the traditional functions of marriage are more likely to have a broader and more scripted view of married life that is likely to foster stability and happiness in their marriages.

By contrast, adults who subscribe to a soulmate model of marriage that is characterized by a conditional, romantic view of marriage are probably less likely to enjoy successful marriages. Specifically, adherents of the soulmate model believe that marriage's primary function is to foster emotional intimacy between spouses, and that childbearing, childrearing, economic cooperation, and other social functions of marriage are not that important (Amato, 2009). Young married adults who hold this view are likely to be disappointed when they face stresses-such as the arrival of a child or a difficult work situation-that make it difficult for them or their partner to sustain a high level of emotional intimacy at all times in their marriage (Karney and Bradbury, 1995). These challenges or stresses, which regularly impinge on most marriages, are likely to shake the marital faith of spouses who hold to a soulmate model; in turn, the marital disillusionment that follows may lead many soulmate-minded spouses to be less likely to extend and maintain love to their partner.

Second, adherents of the soulmate model embrace an ethic of conditional love-e.g., remaining married so long as their love shall last-rather than an ethic of unconditional marital permanence-e.g., remaining married, for better or for worse, so long as they both shall live. That is, because they think marriage is largely designed to advance personal growth and individual fulfillment, young married adults who take a soulmate approach to marriage are likely to embrace a conditional ethic of love that provides them with the option of exiting the marriage if it proves unfulfilling or stifling (Coontz, 2005; Giddens, 1991). This conditional approach to love, however, is not as likely to foster trust and commitment in a relationship-especially when a spouse's partner knows that his or her love is conditional (Wilcox and Nock, 2006). In turn, lower levels of trust and commitment probably make spouses less likely to invest emotionally in their partner (Amato and Rogers, 1999; Nock, 1995). 


\subsection{Social integration}

Spouses are also likely to benefit from being integrated into social structures that affirm their commitment to one another and to marriage more generally (Wilcox and Nock, 2006). For instance, in comparing cohabitation to marriage, Nock points out that these two relationships are viewed differently by "friends, relatives, employers, the state, the IRS, and other people" and that these social structures can be as consequential for relationship quality and stability as how these relationships are "experienced by the particular individuals involved in them" (Nock, 2006, p. 9). If his argument is extended to more and less institutionalized marriages, it suggests that couples who enjoy the support of social networks and other institutions, such as friends, extended family, or religious congregations, will be more likely to enjoy stable, high-quality relationships than couples who do not enjoy the support of these social structures for their marriages.

Social networks are important for at least three reasons. First, these networks tend to reinforce role commitment to marital norms by lending legitimacy to them, as well as by according status to spouses who conform to legitimate marriage norms and stigma to spouses who break these norms (Nock, 1998). Second, these networks can lend social, emotional, and financial support to spouses who are struggling in their marriages or with other difficulties, such as unemployment or illness, thereby reducing the stresses that can otherwise undercut a marriage (Karney and Bradbury, 1995; Nock, 1995; Nock et al., 2008). Third, these networks can provide couples with models of strong marriages that inspire them to invest in their own marriages and to work through difficulties (Wilcox, 2004).

Religious institutions can also be important sources of social structural support for marriage. A large body of social scientific literature indicates that religious belief and practice is positively associated with marital quality and stability (e.g., Call and Heaton, 1997; Lambert and Dollahite, 2006; Mahoney et al., 2001; Wilcox and Nock, 2006). Among other things, religious faith is associated with the "sanctification" of marriage, where spouses endow marriage with transcendent significance; when they see God as present in their marriages, spouses are motivated to invest themselves in their marriages and are more likely to take a rose-colored view of their marriage and their spouse (Mahoney et al., 2003; Wilcox and Nock, 2006). Religious couples are also more likely to identify with relationship-related norms such as sexual fidelity, forgiveness, and unconditional love-all of which tend to foster good marriages (Call and Heaton, 1997; Lambert and Dollahite, 2006). Finally, churches situate couples in social networks that lend normative and social support to their relationships (Wilcox, 2004). For all these reasons, spouses who share a strong commitment to religious faith are probably more likely to enjoy high levels of marital quality and stability.

Given the deeply pluralistic character of contemporary life, and the rise of expressive individualism as a central feature of the contemporary culture, social integration may be particularly important in reinforcing the power and the value of traditional norms related to marriage. That is, spouses who endorse traditional norms about marital permanency, children, mutual aid, and gender specialization may only benefit from adhering to an institutional schemata if they are embedded in social structures that reinforce these norms, lend legitimacy to them, and monitor their expression. Without these plausibility structures (Berger, 1968), these norms may do little to shape marital behavior or, worse yet, may be used to legitimate bad behavior in marriages.

For instance, traditionally-minded men who are not regular churchgoers may rely on traditional gender beliefs to justify their lack of engagement in the emotional and practical dimensions of marriage and family life or an abusive or authoritarian style of familial engagement (McQuillan and Ferree, 1998; Wilcox, 2004). By contrast, traditionally-minded men who are integrated into a religious community may be encouraged by their peers to connect their traditional beliefs with an engaged and expressive style of marital relating and be stigmatized if they are abusive or authoritarian with their wife (Wilcox, 2004). This raises the possibility that the institutional model of marriage only works to strengthen marriages when marital norms are appropriately coupled to marriage-friendly social structures. In other words, if the population of married couples is divided up into different clusters, couples are probably most likely to enjoy strong and happy marriages when they both subscribe to institutional norms about marriage and are embedded in social structures that support those norms.

Thus, we test the following two hypotheses:

Hypothesis 2: Marriages organized according to institutional norms and that are integrated into supportive religious and social structures enjoy higher levels of marital quality and stability.

Hypothesis 3: Marriages organized according to institutional norms without the benefit of supportive religious and social structures experience lower levels of marital quality and stability.

Finally, it is also possible that spouses organize marriages by forging a hybrid model of marriage that incorporates features of the soulmate and institutional models of marriage (Amato, 2009; Wilcox and Nock, 2006). In particular, couples may take a "companionate" approach to marriage that combines a contemporary appreciation for "love as the basis of marriage" with a traditional appreciation of norms of marital permanency and gender specialization, as well as religious faith (Amato, 2009, 81; Wilcox, 2004). This hybrid model could serve contemporary couples well by allowing them to embrace aspects of the increasingly expressive character of modern life while at the same time enjoying norms and social supports that furnish a measure of meaning, order, and stability to marital love, and temper unrealistic expectations of the emotional possibilities of married life. Thus, we test the following final hypothesis:

Hypothesis 4: Companionate marriages that prioritize romantic love but also value marital permanency and benefit from supportive religious and social structures experience higher levels of marital quality and stability. 


\section{Methods}

\subsection{Data and sample}

The Marriage Matters Survey (MMS) is a panel survey of newlywed couples that was conducted between 1998 and 2004 (Nock et al., 2008). The first wave was administered to couples who were randomly selected from marriage licenses in 17 randomly-selected parishes (out of 60) in Louisiana between 1998 and 2000, shortly after the couples married. The sample contained an oversample of couples who elected to marry under Louisiana's more stringent covenant marriage option. ${ }^{3}$ The response rate of the initial survey was 49 percent (Nock et al., 2008). The second and third waves were administered 18 and $30-$ 42 months after the first wave.

For the analysis of divorce discussed below, all participants were included ( $N=707$ women and men). Because we drew the outcome measures of marital satisfaction and conflict from the second wave, we could only include the Marriage Matters participants in the survey who participated in Waves 1 and 2 and were still married in Wave 2 for the marital conflict and quality analyses. We had 520 women and 430 men for these analyses.

Descriptive statistics in Table 1 show the participants' demographic characteristics. Most participants were in their mid to late 20s. ${ }^{4}$ Many had finished some college. The majority of the sample was White, Non-Hispanic, though 21 percent of the wives and 16 percent of the husbands reported that they were of other race/ethnic groups. The average total household income was around $\$ 46,000$. By the first wave, 35 percent of the participants had children. By the third wave, 14 percent of the couples had experienced a divorce.

This sample was demographically different from the national population in 1998. For example, the average age and median income was lower in this sample than in the married sample from the 1998 GSS (analysis not shown). Further, there were more African-American and other other race/ethnic minority individuals in this study than in the 1998 GSS. Importantly, however, marital satisfaction for wives in this sample was no different than the wives in the 1998 GSS and husbands' marital satisfaction was only slightly higher than husband's satisfaction in the 1998 GSS.

\subsection{Measures}

\subsubsection{Dependent variables}

Marital satisfaction was created by taking the mean of seven W2 (e.g., 18 month follow-up) items that asked the question, "Right now, how satisfied would you say you are with each of the following aspects of your marriage?" These items included love, communication, emotional intimacy, physical intimacy, conflict resolution, marital fairness, and the overall relationship. Chronbach's alpha for the scale was .90 for both husbands and wives. Because the variable was skewed toward high satisfaction (the mean was 4 on a scale of 5), we dichotomized the variable with a 1 meaning high satisfaction (greater than 4). Those with satisfaction at 4 or less received a 0 for this variable.

Marital conflict was created by taking the mean of 15 W2 items that asked participants how frequently they disagreed over different topics. Example items are "handling family finances", "spending time together", and "philosophy of life". Chronbach's alpha was .86 for wives and .85 for husbands. Like marital satisfaction, this variable was skewed (the mean was 2 on a scale of 5). Consequently, we dichotomized this variable. Participants who scored above 2 received a 1 on the high conflict variable. Results using OLS regression and the full conflict scale were similar to the logistic regressions using the dichotomized variable. We used the logistic regression results in this study because of the restricted variance of these two outcome variables. Doing this also kept the analyses consistent with the divorce outcome.

Finally, divorce was a dependent variable and it was dichotomous. If couples were separated or divorced by W3, they received a code of 1 .

\subsubsection{Independent variables}

The independent variables were taken from the first wave. We did this to satisfy the requirement that the independent variables precede the dependent variables.

One of the main tasks of this study was to identify different characteristics that indicated whether individuals had an institutional or soulmate orientation toward marriage, and then to see how these characteristics might be usefully organized in different latent classes. We were able to identify six characteristics similar to those discussed in Amato (2009): purpose of marriage, importance of marital stability, the role of individualism in marriage, gender role traditionalism, social networks, and religious attendance.

\footnotetext{
${ }^{3}$ None of the divorce or marital satisfaction findings changed in Tables 4 and 5 when we controlled for whether couples were in a covenant marriage (analysis not shown). Wives' marital conflict analyses were also unchanged. However, the covenant marriage control completely mediated the association between the husband's soulmate socially integrated group and marital conflict. This may indicate a selection effect for those who chose a covenant marriage compared to those who did not-at least for husbands.

${ }_{4}^{4}$ Although the age range indicates that we did have some older individuals in our sample, 90 percent of the husbands and 95 percent of the wives were under age 45. Further, controlling for the number of times married (likely the reason we have some older individuals) did not change the findings (analysis not shown).
} 
Table 1

Descriptive statistics.

\begin{tabular}{|c|c|c|c|c|c|c|}
\hline & \multicolumn{3}{|l|}{$\underline{\text { Wives }}$} & \multicolumn{3}{|c|}{ Husbands } \\
\hline & $\mathrm{M}$ & Std & Range & M & Std & Range \\
\hline \multicolumn{7}{|l|}{ Individual variables } \\
\hline W2 High marital satisfaction & .52 & .50 & $0-1$ & .52 & .50 & $0-1$ \\
\hline W2 High conflict & .45 & .50 & $0-1$ & .51 & .50 & $0-1$ \\
\hline W1 Traditional purpose of marriage & 2.17 & .77 & $1-5$ & 2.46 & .82 & $1-5$ \\
\hline W1 Importance of marital stability & 4.00 & .73 & $1.5-5$ & 3.98 & .77 & $1-5$ \\
\hline W1 Individualism in marriage & 3.51 & 1.08 & $1-5$ & 3.59 & 1.05 & $1-5$ \\
\hline W1 Religious attendance & 2.36 & .80 & $1-3$ & 2.09 & .89 & $1-3$ \\
\hline W1 Family role traditionalism & 2.54 & .81 & $1-5$ & 2.74 & .79 & $1-5$ \\
\hline W1 Social support for their marriage & 3.71 & .42 & $1-4$ & 3.63 & .44 & $1-4$ \\
\hline W1 Age & 28.64 & 8.87 & $16-90$ & 30.81 & 9.60 & $19-75$ \\
\hline Black $^{\mathrm{a}}$ & .15 & .35 & $0-1$ & .12 & .32 & $0-1$ \\
\hline Other $^{\mathrm{a}}$ & .06 & .24 & $0-1$ & .04 & .19 & $0-1$ \\
\hline W1 Education & 14.00 & 2.22 & $8-20$ & 13.73 & 2.46 & $6-22$ \\
\hline Number of marriages & 1.41 & .69 & $1-4$ & 1.43 & .71 & $1-4$ \\
\hline Couple level variables & \multicolumn{2}{|l|}{$\mathrm{M}$} & \multicolumn{2}{|l|}{ Std } & \multicolumn{2}{|l|}{ Range } \\
\hline Divorced by W3 & \multirow{3}{*}{\multicolumn{2}{|c|}{$\begin{array}{l}.14 \\
\$ 45,529 \\
.35\end{array}$}} & \multirow{3}{*}{\multicolumn{2}{|c|}{$\begin{array}{l}.34 \\
30,695 \\
.48\end{array}$}} & \multirow{3}{*}{\multicolumn{2}{|c|}{$\begin{array}{l}0-1 \\
\$ 0-\$ 190,000 \\
0-1\end{array}$}} \\
\hline W1 Income & & & & & & \\
\hline W1 Presence of children & & & & & & \\
\hline
\end{tabular}

a Omitted category is White, Non-Hispanic.

To assess participants' views of the purpose of marriage, we took the mean of four variables. These variables asked whether marriage was necessary to complete a man, to complete a woman, whether having children was one of the most important reasons for marrying, and whether financial stability was an important reason for marrying. Higher scores meant that participants felt that marriage had more traditional purposes. Chronbach's alpha was .74 for both wives and husbands. Table 1 shows that, on average, wives had a less traditional view of the purpose of marriage; husbands were evenly split between more and less traditional views of the purpose of marriage.

We created a scale measuring the importance of marital stability by taking the mean of four variables. Two variables asked participants about marriage and divorce (e.g., a terrible marriage is worse than a divorce). The other two asked about government regulation of divorce (e.g., divorces should be harder to get). Higher scores meant that participants believed that marriage should be stable and divorces uncommon. Chronbach's alpha was .71 for wives and .77 for husbands. On average, both wives and husbands rated the importance of marriage stability highly (see Table 1).

A single item measured the role of individualism in marriage. This item asked participants to agree or disagree with the statement, "In a successful marriage, the partners must have freedom to do what they want individually". Higher scores meant that participants agreed with this statement. On average, both wives and husbands felt that individualism was important in marriage (see Table 1 ).

Family role traditionalism assessed how participants felt about gendered family roles. To create this variable, we took the mean of five variables concerning men's and women's roles in the workplace and home. These variables included whether families suffer when a wife works full time, whether the husbands' job is to provide and the wife's job is to look after the family, it's best if the man works and the wife stays at home, if childcare is primarily the wife's responsibility, and if women are better at childcare than men "by nature". Higher scores meant more traditional orientations. The Chronbach's alpha was .80 for both wives and husbands.

To assess integration in social networks we took a mean of eight items. These items asked participants to rate how much they felt that their family and friends currently approved of and supported their marriage. Higher scores meant higher support and approval. Chronbach's alpha was .93 for wives and .95 for husbands.

Finally, religious attendance was taken from a measure that asked participants how often they attended worship services (with or without their spouse). We recoded the variable such that those who attended less than once per month received a 1 on the variable, those who attended once a month received a 2 , and those who attended multiple times a month received a 3. Wives attended more often than husbands (see Table 1 ).

We also controlled for age, race, education, income, and the presence of children.

\subsection{Analysis}

First, we examined whether latent classes of spouses existed in the data based on the six key characteristics this paper focuses upon: traditional purpose of marriage, a commitment to marital permanency, individualism in marriage, religious attendance, family role traditionalism, and social support for marriage. Somewhat analogous to factor analysis that assesses how different variables hang together in unobserved factors, latent class analysis used participants' variables to search for unobserved classes of individuals (Lanza et al., 2003). Although we hypothesized the existence of three classes 
or types of marriages-institutional, companionate, and soulmate-based on theory, we were aware that a different solution might fit the data best. Consequently, we ran a two-class, three-class, four-class, and five-class solution and compared three measures of fit (the $G^{2}$ statistic, AIC, and BIC) to see which solution provided the best fit as recommended in Lanza et al. (2003).

Because latent class analysis is generally run using dichotomous variables (Lanza et al., 2003) we first dichotomized the six characteristic variables using a mean split. Those above the mean received a 1 or "high" value for the variable, those at or below the mean received a 0 or "low" value for the variable. We then ran the latent class analysis specifying different numbers of classes. The LCA suggested four classes fit the data best; we detail these classes below.

In the final analysis, we regressed the dependent variables on class membership while including the control variables. This allowed us to examine whether class membership at W1 predicted the W2 outcome variables.

In all of the analyses we ran wives' and husbands' analyses separately. We conducted the analyses separately for a number of reasons. First, we chose to analyze the data separately so that we did not violate the regression assumption of an uncorrelated error structure. Second, divorce is often a unilateral phenomenon. Frequently one spouse is not overly dissatisfied prior to the divorce; that spouse may not want a divorce. Consequently, because divorce is not necessarily a dyadic process we felt it was appropriate to run the analyses separately. Finally, we ran the analyses separately because we wanted to see how spouses' own class membership related to their own perceptions of marital satisfaction and conflict. $^{5}$

Some might question whether spouses' attitudes about marriage are independent enough to warrant such treatment. We examined whether the six main marriage variables-traditional purpose of marriage, importance of marital stability, individualism, religious attendance, family role traditionalism, and social integration-were correlated between wives and husbands (not shown). All of the correlations were significant and ranged from .22 to .62. Thus, participants' spousal attitudes about marriage explained between 5 and 38 percent of the variance leaving $62-95$ percent of the variance in these variables unshared. Likewise we examined the congruency of class membership that was based on these variables. We found that 54 percent of the couples were not congruent in their class membership. Finally, we correlated the outcome variablesW2 marital satisfaction and conflict. The spouses' outcome variables correlated at .58 and .55 , respectively ( $p<.001)$. Thus, although the outcome variables were correlated there is a lot of variance (between 67 and 70 percent) that was independent. Because of all of these between-spouse differences we felt confident that using individuals (rather than couples) as the unit of analysis was a sound analytic choice.

\section{Results}

\subsection{Latent class analysis}

For wives, selecting which solution best represented the data was fairly straight forward. Although we had theorized that a three-class solution would fit the data best, a four-class solution actually provided the best fit. One rough indicator was that the $G^{2}$ statistic of the four-class solution (35.71) was less than the degrees of freedom (36) (Lanza et al., 2003). Further, the AIC and BIC were lowest in the four-class condition. The other solutions simply fit the data worse. ${ }^{6}$ Thus, we went with a fourclass solution for the wives.

For husbands, we had a more difficult time selecting the best fitting model. None of the solutions produced a $G^{2}$ statistic that was lower than the degrees of freedom. Despite this, it was clear from the $G^{2}$, AIC, and BIC that either a threeor a four-class solution fit best. Unfortunately the AIC went down from the three-class to the four-class solution (from 123.04 to 95.97 ) whereas the BIC went up (from 214.26 to 219.12). We decided that because the $G^{2}$ statistic was cut almost in half from the three-class to the four-class solution (83.04 to 41.97) that a four-class solution best fit the husbands' data.

Tables 2 and 3 show Rho $(\rho)$ and Gamma $(\gamma)$ coefficients for the wives' and husbands' LCA, respectively. The gamma coefficients show the proportion of individuals in each class. So, for example, 14 percent of the sample of wives fit into the first class, "soulmate supported" (Table 2). The Rho coefficient gives the probability of being in the above-average response category on each variable conditional on being in a particular class. Thus, for example, wives in the first class were only 36 percent likely to have an above-average response on the traditional purposes of marriage scale, but 94 percent likely to have above average levels on the individualism item.

Just as we had not anticipated having four classes, we had also not anticipated some of the patterns of the Rho coefficients. Based on these coefficients, we called two of the classes "soulmate supported" and "soulmate not supported". Both soulmate classes were characterized by low probabilities of endorsing traditional purpose of marriage, the importance of marital stability, religious attendance, and family role traditionalism (see Table 2). Both were also most likely to score high on individualism. The main difference between these two groups was that soulmate supported wives were almost 100 percent likely to be above average in the social support they received for their marriage, whereas only one-third of the members of the other soulmate model were likely to report high levels of support for their marriage.

\footnotetext{
5 It is possible that congruency in class membership influences the marital outcomes. We discuss this issue later.

6 Data available on request.
} 
Table 2

Latent class analyses of wives.

\begin{tabular}{|c|c|c|c|c|}
\hline & $\begin{array}{l}\text { Soulmate, supported } \\
\rho \text { Coefficients (probability of } \\
\text { having above mean levels of } \\
\text { the characteristic) }\end{array}$ & $\begin{array}{l}\text { Soulmate, not supported } \\
\rho \text { Coefficients (probability of } \\
\text { having above mean levels of } \\
\text { the characteristic) }\end{array}$ & $\begin{array}{l}\text { Religious companionate } \\
\rho \text { Coefficients (probability of } \\
\text { having above mean levels of } \\
\text { the characteristic) }\end{array}$ & $\begin{array}{l}\text { Secular institutional } \\
\rho \text { Coefficients (probability of } \\
\text { having above mean levels of } \\
\text { the characteristic) }\end{array}$ \\
\hline $\begin{array}{l}\text { Traditional purpose } \\
\text { of marriage }\end{array}$ & .36 & .16 & .49 & .75 \\
\hline $\begin{array}{l}\text { Importance of } \\
\text { marital stability }\end{array}$ & .17 & .17 & .74 & .56 \\
\hline Individualism & .94 & .53 & .52 & .53 \\
\hline Religious attendance & .15 & .30 & .84 & .60 \\
\hline $\begin{array}{l}\text { Family role } \\
\text { traditionalism }\end{array}$ & .31 & .07 & .62 & 1.00 \\
\hline $\begin{array}{l}\text { Social support for } \\
\text { their marriage }\end{array}$ & .99 & .37 & .81 & .35 \\
\hline $\begin{array}{l}\gamma \text { Coefficient } \\
\text { (Proportion of } \\
\text { sample in class) }\end{array}$ & .14 & .26 & .44 & .16 \\
\hline
\end{tabular}

$G^{2}(36, N=707)=35.71, p>.05$.

Table 3

Latent class analysis of husband.

\begin{tabular}{|c|c|c|c|c|}
\hline & $\begin{array}{l}\text { Soulmate, supported } \\
\rho \text { Coefficients (probability of } \\
\text { having above mean levels of } \\
\text { the characteristic) }\end{array}$ & $\begin{array}{l}\text { Soulmate, not supported } \\
\rho \text { Coefficients (probability of } \\
\text { having above mean levels of } \\
\text { the characteristic) }\end{array}$ & $\begin{array}{l}\text { Religious companionate } \\
\rho \text { Coefficients (probability of } \\
\text { having above mean levels of } \\
\text { the characteristic) }\end{array}$ & $\begin{array}{l}\text { Secular institutional } \\
\rho \text { Coefficients (probability of } \\
\text { having above mean levels of } \\
\text { the characteristic) }\end{array}$ \\
\hline $\begin{array}{l}\text { Traditional purpose } \\
\text { of marriage }\end{array}$ & .22 & .01 & .53 & .99 \\
\hline $\begin{array}{l}\text { Importance of } \\
\text { marital stability }\end{array}$ & .24 & .01 & .86 & .65 \\
\hline Individualism & .99 & .01 & .50 & .64 \\
\hline Religious attendance & .18 & .01 & .91 & .30 \\
\hline $\begin{array}{l}\text { Family role } \\
\text { traditionalism }\end{array}$ & .19 & .02 & .61 & .59 \\
\hline $\begin{array}{l}\text { Social support for } \\
\text { their marriage }\end{array}$ & .55 & .06 & .73 & .51 \\
\hline $\begin{array}{l}\gamma \text { Coefficient } \\
\text { (proportion of } \\
\text { sample in class) }\end{array}$ & .21 & .20 & .39 & .20 \\
\hline
\end{tabular}

$G^{2}(36, N=707)=41.97, p>.05$.

Thus, one of the reasons that we found four classes instead of three was that there appeared to be two groups of soulmate wives.

We also found two classes of marriage that came closer to the institutional model of marriage detailed in the first half of this article. Our companionate and institutional classes were somewhat surprising in their composition, though. We titled the companionate group "religious companionate" and the traditional group "secular institutional". Of the four classes, the wives in the religious companionate group had the highest probabilities of frequent religious attendance and valuing marital stability (see Table 2). They also were more likely than not to report high social support for their marriage and high family role traditionalism. Interestingly, though, they were equally likely to report high or low levels of the traditional purpose of marriage and individualism. We suspect this is because they are more likely to see marriage's purpose as largely expressive rather than directed towards children and financial cooperation.

Compared with the other classes, the secular institutional wives were the most likely to endorse the traditional purpose of marriage items and family role traditionalism (Table 2). We had expected them to be high on religious attendance and social support for their marriage as well. However, they did not have any more support than the soulmate not supported wives and were less likely to have high levels of religious attendance than the religious companionate. Interestingly, they were also equally likely to be high or low on their individualism score.

The husbands' classes showed the same pattern, except they were more extreme than the wives. Soulmate not supported husbands responded mostly as we had expected. They were unlikely to endorse traditional purposes of marriage, the importance of marital stability, religious attendance, family role traditionalism, and social support for their marriage (Table 3). The unanticipated exception to this finding was that they also did not endorse individualism highly. The soulmate supported 
husbands were similar except that they were more likely to have support from their social circle, and they highly endorsed individualism in marriage.

The religious companionate husbands were like the religious companionate wives-high in the importance of marital stability, religious attendance, family role traditionalism and social integration but equally likely to have high or low levels of traditional purpose of marriage and individualism (Table 3). It is interesting that this class of husbands was the most likely to be highly socially supported. The secular institutional husbands were even more extreme than the secular institutional wives in that almost 100 percent had above average levels of traditional purpose of marriage, and few of them had above average levels of religious attendance.

\subsection{Latent class membership and marriage outcomes}

\subsubsection{Marital quality}

Table 4 provides support for Hypotheses 3 and 4, and more mixed evidence when it comes to Hypotheses 1 and 2. Compared with the religious companionate wives, secular institutional wives had 50 percent lower odds of reporting high levels of marital satisfaction (see Table 4). Although soulmate wives who were supported and soulmate wives who were not also had lower odds of reporting high levels of marital satisfaction, the differences were not statistically significant.

Relative to religious companionate wives, the other three groups were all more likely to report higher odds of high marital conflict. Soulmate wives who were socially supported had 55 percent higher odds of reporting conflict, soulmate wives who were not socially supported had 67 percent higher odds of reporting conflict, and secular institutional wives had 103 percent higher odds.

The findings were similar for husbands (Table 4). Secular institutional husbands were less likely than religious companionate husbands to report having high satisfaction. Further, relative to the religious companionate husbands, soulmate supported husbands and secular institutional husbands had odds that were 95-146 percent higher of reporting high levels of conflict. Thus, consistent with Hypotheses 3 and 4, the religious companionate spouses generally enjoyed the highest levels of marital quality and the secular institutional spouses experienced the lowest quality marriages.

\subsubsection{Divorce}

The findings were even stronger regarding class membership and the odds of divorce. For wives, the three groups were at least 144 percent more likely to have divorced by Wave 3 relative to the religious companionate (Table 5). Interestingly, only soulmate husbands were more likely to divorce compared to the religious companionate. Soulmate supported and soulmate not supported husbands had 166 percent and 148 percent (respectively) higher odds of divorcing relative to the religious companionate (Table 5). Secular institutional husbands were no more likely to divorce than were religious companionate

Table 4

Likelihood of high Wave 2 marital satisfaction and conflict based on respondents Wave 1 class membership.

\begin{tabular}{|c|c|c|c|c|c|c|c|c|c|c|c|c|}
\hline & \multicolumn{6}{|c|}{ Wives $(N=520)$} & \multicolumn{6}{|c|}{ Husbands $(N=430)$} \\
\hline & \multicolumn{3}{|c|}{ High satisfaction } & \multicolumn{3}{|c|}{ High conflict } & \multicolumn{3}{|c|}{ High satisfaction } & \multicolumn{3}{|c|}{ High conflict } \\
\hline & $\bar{b}$ & StE & $e^{b}$ & $B$ & StE & $e^{b}$ & $\bar{b}$ & StE & $e^{b}$ & $\bar{b}$ & StE & $e^{b}$ \\
\hline W1 R Soulmate, supported ${ }^{\mathrm{a}}$ & -.24 & .26 & .79 & $.44^{\dagger}$ & .26 & 1.55 & -.19 & .25 & .83 & $.67^{* * *}$ & .26 & 1.95 \\
\hline W1 R Soulmate, not supported ${ }^{\mathrm{a}}$ & -.21 & .24 & .81 & $.51^{*}$ & .24 & 1.67 & .32 & .60 & 1.37 & -.90 & .67 & .40 \\
\hline W1 R Secular institutional ${ }^{\mathrm{a}}$ & $-.69^{*}$ & .30 & .50 & $.71^{*}$ & .30 & 2.03 & $-.90^{* *}$ & .26 & .41 & $.90^{* *}$ & .27 & 2.46 \\
\hline
\end{tabular}

Note. All models control for age, race, education, income, number of marriages, and presence of children.

a Omitted category is religious companionate.

$+p<.10$.

$p<.05$.

$p<.01$.

Table 5

Likelihood of divorce by W3 based on Wave 1 class membership.

\begin{tabular}{|c|c|c|c|c|c|c|}
\hline & \multicolumn{3}{|c|}{ Wives $(N=707)$} & \multicolumn{3}{|c|}{ Husbands $(N=707)$} \\
\hline & $b$ & StE & $e^{b}$ & $b$ & StE & $e^{b}$ \\
\hline W1 R Soulmate, supported ${ }^{\mathrm{a}}$ & $.92^{* *}$ & .35 & 2.51 & $.98^{* *}$ & .31 & 2.66 \\
\hline W1 R Soulmate, not supported ${ }^{\mathrm{a}}$ & $.98^{* *}$ & .29 & 2.66 & $.91^{* *}$ & .42 & 2.48 \\
\hline W1 R Secular institutional ${ }^{\mathrm{a}}$ & $.90^{* *}$ & .34 & 2.44 & .44 & .35 & 1.55 \\
\hline
\end{tabular}

Note. All models control for age, race, education, income, number of marriages, and presence of children.

a Omitted category is religious companionate.

** $p<.01$. 
husbands. Accordingly, Table 5 provided some support for Hypotheses 2 and 4, which suggest that institutional and companionate marriages are more stable than soulmate marriages.

\section{Discussion}

This study has sought to understand whether a soulmate model of marriage or an institutional model of marriage is more likely to foster marital quality and stability among contemporary married men and women. Analyzing a sample of 1414 married men and women who got married in Louisiana between 1998 and 2000, we find some evidence that the soulmate model of marriage fosters marital quality and that the institutional model of marriage fosters marital stability. Nevertheless, our latent class analysis indicates that the most successful contemporary marriages are religious companionate marriages that combine elements of both soulmate and institutional models.

Specifically, this study's latent class analysis suggests that marriages that combine most elements of the institutional model-especially high levels of normative commitment to marital stability and gender role traditionalism, as well as high levels of religious attendance and social network support for marriages-but do not necessarily embrace the traditional purposes of marriage are happiest. Husbands and wives who are in our religious companionate category tend to enjoy the highest levels of marital quality and the lowest levels of divorce (see Tables 4 and 5).

We suspect that many of these Louisiana couples are picking up on cultural messages now emanating from religious institutions-especially evangelical Protestant ones-that encourage couples to focus on the expressive dimension of married life and to value marital permanency as well as gender complementarity in marriage (Cherlin, 2009; Wilcox, 2004). This religious companionate model of marriage allows couples to benefit from the normative and social structural supports associated with a traditional model of marriage and at the same time to embrace the expressive dimension of married life that has become so prominent in contemporary society. As Cherlin (2009) has pointed out, these cultural elements stand in tension, at least theoretically, in the United States' approach to marriage. But they do seem to be working relatively well here in practice, probably in large part because these couples are embedded in communities that temper the more extreme elements of American expressive individualism.

By contrast, spouses who adhere to a secular institutional model of marriage-that is, who embrace the traditional norms and purposes associated with married life but are less likely to enjoy social structural support for their beliefs-experience the lowest levels of marital quality. Not surprisingly, however, their divorce rates are somewhat lower than spouses who take a soulmate approach to marriage, especially in the case of husbands. But the poor quality of their marriages, which tend to be marked by lower levels of happiness and higher levels of marital conflict than their peers, suggests that the institutional model of marriage does not work unless it is embedded in social structures that provide social support, status, and legitimacy to the norms and beliefs associated with this model.

So how do spouses who take a soulmate model approach to marriage fare? Recall that the soulmate approach combines low levels of normative commitment to marital permanency and the traditional purposes of marriage, high levels of individualism, low religiosity, and more egalitarian gender ideals. Moreover, these couples have varying levels of social network support; some are "integrated" into networks of friends and family that support their marriages, and some are not. This study finds that couples who take a soulmate approach to marriage are about as satisfied with their marriages as couples who take a religious companionate approach to marriage. But they are significantly more likely to experience conflict and divorce than are men and women in the religious companionate models. In fact, when it comes to conflict and divorce, spouses who embrace the soulmate model and receive social network support for their marriages generally fare no better than spouses who embrace the soulmate model without social network support. This suggests that couples who embrace the soulmate model typically experience more volatility and instability in their relationships; or, in Coontz's words, such relationships are "more brittle".

This study has a number of limitations. First, given that the sample comes from Louisiana, the findings of this study cannot necessarily be generalized to the United States as a whole. Future research will have to determine if the patterns found in this study are also found in the U.S. as a whole. Second, even though we rely on longitudinal data, we do not explore the possibility that marital quality predicts spouses' normative views or patterns of social integration. It could be, for instance, that unhappy couples disengage from religious practice (Booth et al., 1995). Future work will have to explore this possibility. Third, we do not explore the possibility that these patterns vary for married couples who are parents versus married couples who are not parents. This is an important limitation because many of the couples in this sample had not yet had children, and because some research indicates that the soulmate model is more successful among childless couples and the institutional model is more successful among couples with children in the home (Wilcox and Dew, 2010).

Another limitation was the problem of congruence. We could not tease out the extent to which the findings resulted from differential patterns of congruence. When husbands' and wives' class membership were crossed, we found many congruent spouses, but also many who were not. The two largest groups are congruent religious companionate and congruent integrated soulmates. But there is also a large amount of non-congruent spouses. As noted above, non-congruent spouses outnumber congruent spouses (54 percent vs. 46 percent, respectively).

Spousal congruence and class membership was not independent. Around two-thirds of class-congruent spouses were religious companionate (65 percent), whereas very few secular institutional participants were married to another secular institutional participant (only 6 percent of the congruent spouses). Consequently, it may be the case that part of the reason 
religious companionate did better than other couples was because they were most likely to be married to someone who is like them. Unfortunately, we could not test this hypothesis using a dummy variable that indicated whether couples were congruent in their marriage. Because the majority of congruent spouses were religious companionate, such a variable would simply be a proxy for being religious companionate and the results would be meaningless. Thus, we do not know how much congruence played a role in shaping marital success.

In spite of these limitations, this study does lend substantial support to Steven Nock's basic claims that love alone is a flimsy foundation for a relationship, and that couples benefit from the norms and social structures associated with the institution of marriage (Nock 1995, 1998). Indeed, spouses who identify most strongly with norms of marital permanency and gender specialization and are embedded in marriage-friendly social networks and religious institutions are most likely to enjoy stable, high-quality marriages. Accordingly, this study suggests couples experience marriage in categorically different terms, and the couples who are most likely to succeed are those couples who most embrace and are embraced by marriagefriendly norms, networks, and institutions in the United States.

But this study also reveals an important caveat to a story that is otherwise largely consistent with Nock's institutional theory of marriage. In today's society, the institutional model of marriage only appears to work when it is coupled with a proper appreciation for the expressive dimension of married life. Here, we were wrong to predict that men and women would be happiest in marriages that focused on traditional marital goods like children and mutual aid. Instead, a neo-traditional model of marriage that combines elements of the new and old seems most likely to engender success in today's marriages (Wilcox and Nock, 2006). In other words, couples are most likely to enjoy a long-term marriage that comes close to approximating the soulmate model when they build their marriage on a firm institutional foundation that encompasses, among other things, a normative commitment to marital permanency, friends and family who support their marriage, and a religious community that lends transcendent power to their wedding vows.

\section{References}

Amato, P.R., 2009. Institutional, companionate, and individualistic marriage: a social psychological perspective on marital change. In: Peters, H.E., Kamp Dush, C.M. (Eds.), Marriage and Family: Complexities and Perspectives. Columbia University Press, New York, pp. 75-90.

Amato, P.R., 2005. The impact of family formation change on the cognitive, social, and emotional well-being of the next generation. The Future of Children 15, 75-96.

Amato, P.R., Rogers, S.J., 1999. Do attitudes toward divorce affect marital quality? Journal of Family Issues 20, 69-86.

Amato, P.R., Booth, A., Johnson, D.R., Rogers, S.J., 2007. Alone Together: How Marriage in America is Changing. Harvard University Press, Cambridge, MA. Bell, D., 1976. The Coming of Post-industrial Society: A Venture in Social Forecasting. Basic Books, New York.

Bellah, R., Madsen, R., Sullivan, W., Swidler, A., Tipton, S., 1985. Habits of the Heart. University of California Press, Los Angeles.

Berger, P., 1968. The Sacred Canopy: Elements of a Sociological Theory of Religion. Doubleday, Garden City, NY.

Bianchi, S.M., Robinson, J.P., Milkie, M.A., 2006. Changing Rhythms of American Family Life. The American Sociological Association's Rose Series in Sociology.

Booth, A., Johnson, D., Branaman, A., Sica, A., 1995. Belief and behavior: does religion matter in today's marriage. Journal of Marriage and the Family 57, 661671.

Brines, J., Joyner, K., 1999. The ties that bind: principles of cohesion in cohabitation and marriage. American Sociological Review 64, $333-355$.

Brown, S., Booth, A., 1996. Cohabitation versus marriage: a comparison of relationship quality. Journal of Marriage and Family 58, 668-678.

Call, V.R.A., Heaton, T.B., 1997. Religious influence on marital stability. Journal for the Scientific Study of Religion 36, $382-392$.

Casper, L.M., Bianchi, S.M., 2002. Continuity and Change in the American Family. Sage Publications, Thousand Oaks, CA.

Cherlin, A.J., 2009. The Marriage-Go-Round: The State of Marriage and Family in America Today. Knopf, New York.

Cherlin, A.J., 2004. The deinstitutionalization of American marriage. Journal of Marriage and Family 66, 848-861.

Coontz, S., 2005. Marriage, A History: From Obedience to Intimacy, or How Love Conquered Marriage. Viking, New York.

Coontz, S., 1992. The Way We Never Were: American Families and the Nostalgia Trap. Basic Books, New York.

Demaris, A., Longmore, M., 1996. Ideology, power, and equity: testing competing expectations for the perception of fairness in household labor. Social Forces 74, 1043-1071.

Fisher, H., 2005. Why We Love: The Nature and Chemistry of Romantic Love. Henry Holt, New York.

Fowers, B.J., 2000. Beyond the Myth of Marital Happiness. Jossey-Bass, San Francisco, CA.

Giddens, A., 1991. Modernity and Self-Identity. Self and Society in the Late Modern Age. Polity Press, Cambridge.

Hakim, C., 2001. Work-Lifestyle Choices in the 21st Century: Preference Theory. Oxford University Press, New York.

Karney, B.R., Bradbury, T.N., 1995. The longitudinal course of marital quality and stability: a review of theory, methods, and research. Psychological Bulletin $118,3-34$.

Lambert, N.M., Dollahite, D.C., 2006. How religiosity helps couples prevent, resolve, and overcome marital conflict. Family Relations 55, 439-449.

Lambert, N.M., 2008. The threefold cord: marital commitment in religious couples. Journal of Family Issues 29, $592-614$.

Lanza, S.T., Flaherty, B.P., Collins, L.M., 2003. Latent class and latent transition analysis. In: Schinka, J.A., Velicer, W.F. (Eds.), Handbook of Psychology. Research Methods in Psychology, vol. 2.. Wiley, Hoboken, NJ, pp. 663-685.

Mahoney, A., Pargament, K.I., Murray-Swank, A., Murray-Swank, N., 2003. Religion and the sanctification of family relationships. Review of Religious Research 44, 220-236.

Mahoney, A., Pargament, K.I., Tarakeshwar, N., Swank, A.B., et al, 2001. Religion in the home in the 190s and 1990s: a meta-analytic review and conceptual analysis of links between religion, marriage, and parenting. Journal of Family Psychology 15, 559-596.

McLanahan, S., Sandefur, G., 1994. Growing Up with a Single Parent. Harvard University Press, Cambridge, MA.

McQuillan, J., Ferree, M.M., 1998. The importance of variation among men and the benefits of feminism for families. In: Booth, A., Crouter, A. (Eds.), Men in Families: When Do They Get Involved? What Difference Does it Make? Lawrence Erlbaum, Philadelphia, pp. 213-225.

Neff, L.A., Karney, B.R., 2009. Stress and reactivity to daily relationship experiences: how stress hinders adaptive processes in marriage. Journal of Personality and Social Psychology 97, 435-450.

Nock, Steven L., 1995. Commitment and dependency in marriage. Journal of Marriage and the Family 57, 503-514.

Nock, Steven L., 1998. Marriage in Men's Lives. Oxford University Press, New York.

Nock, Steven L., 2005. Marriage as a public issue. The Future of Children 15, 13-32.

Nock, Steven L., 2006. Illustrations of family scholarship: introduction to the special issue. Social Science Research 35, 322-331.

Nock, S.L., Sanchez, L.A., Wright, J.D., 2008. Covenant Marriage: The Movement to Reclaim Tradition in America. Rutgers University Press, New Brunswick, NJ.

Popenoe, D., 2009. Families Without Fathers: Fathers, Marriage, and Children in American Society. Transaction, New Brunswick, NJ. 
Radway, J.A., 1991. Reading the Romance. Women, Patriarchy, and Popular Literature. University of North Carolina Press, Chapel Hill, NC.

Scanzoni, J., 1991. Balancing the policy interests of children and adults. In: Anderson, E., Hula, R. (Eds.), The Reconstruction of Family Policy. Greenwood, West Port, CT, pp. 11-22.

Stanley, S.M., Whitton, S.W., Markman, H.J., 2004. Maybe I do: interpersonal commitment levels and premarital or non-marital cohabitation. Journal of Family Issues $25,496-519$.

Stanley, S.M., Rhoades, G.K., Markman, H.J., 2006. Sliding versus deciding: inertia and the premarital cohabitation effect. Family Relations 55, 499-509.

Thornton, A., 1985. Reciprocal influences of family and religion in a changing world. Journal of Marriage and Family 47, 381-394.

Whitehead, B.D., 1998. The Divorce Culture: Rethinking Our Commitments to Marriage and Family. Knopf, New York.

Whitehead, B.D., Popenoe, D., 2001. Who wants to marry a soul mate? In: The State of Our Unions. The National Marriage Project, pp. 6-16.

Wieselquist, J., Rusbult, C.E., Foster, C.A., Agnew, C.R., 1999. Commitment, pro-relationship behavior, and trust in close relationships. Journal of Personality and Social Psychology 77, 942-966.

Wilcox, W.B., 2004. Soft Patriarchs, New Men: How Christianity Shapes Fathers and Husbands. University of Chicago Press, Chicago.

Wilcox, W.B., Dew, J., 2010. Before and After the Baby Carriage: Parenthood and Marital Quality. University of Virginia Department of Sociology, Working Paper.

Wilcox, W.B., Nock, S.L., 2006. What's love got to do with it? equality, equity, commitment and women's marital quality. Social Forces 84, $1321-1345$. 